Article

\title{
Particle Size Influence on the Transport Classification Labels and Other Flammability Characteristics of Powders
}

\author{
Blanca Castells ${ }^{1,2, * \mathbb{D}}$, Isabel Amez ${ }^{1,2} \mathbb{D}$, Ljiljana Medic ${ }^{1}$ and Javier García Torrent ${ }^{1,2} \mathbb{D}$ \\ 1 Department of Energy and Fuels, E.T.S. Ingenieros de Minas y Energía, Universidad Politécnica de Madrid, \\ Ríos Rosas 21, 28003 Madrid, Spain; isabel.amez@upm.es (I.A.); liliana.medic@upm.es (L.M.); \\ javier.garciat@upm.es (J.G.T.) \\ 2 Laboratorio Oficial Madariaga, LOM (UPM Technical University of Madrid, Spain), C/Eric Kandel, \\ 1 e (TECNOGETAFE), Parque Científico y Tecnológico de la UPM, 28906 Getafe, Spain \\ * Correspondence: b.castells@upm.es; Tel.: +34-676-164-643
}

Received: 16 October 2020; Accepted: 26 November 2020; Published: 1 December 2020

\begin{abstract}
Dust explosions and fires pose an industrial safety problem, due to the human and material losses caused by them. As many fuel processes and material transport generate powder particles, the effect of granulometry in different flammability properties has been studied to define the relationship between both. Deep knowledge of this relationship reduces the self-ignition and self-combustion processes, and the accidents associated with these processes. In this study, six different samples, including biomass, charcoal, and dog food, are tested in three different particle sizes, so differences in their flammability behavior could be appreciated (not only considering fine particles, but also coarse samples). The transport classification test was carried out, obtaining significant results in two samples, where the same material did not self-ignite when tested at its coarse size, but it did when tested at fine particle size. Similar results were obtained when analyzing initial temperature for related-combustion gasses emission: the finer the particle size, the lower the initial temperature. To understand the heat mechanisms, thermal analyses were performed, such as thermogravimetric analysis and differential scanning calorimetry. Finally, a self-ignition risk was assessed for all samples according to their activation energy and characteristic temperature. All the test results lead to conclude that biomasses easily start self-heating process, but its composition difficult the heat transmission to reach self-ignition, while charcoals are more susceptible to self-ignition.
\end{abstract}

Keywords: self-ignition; self-combustion; particle size; biomass; transport classification; thermogravimetry analysis

\section{Introduction}

Spontaneous combustion, or spontaneous ignition, is the process by which a substance begins its combustion without an external ignition source. During this process, the inner exothermic reactions raise oxidation velocity, which increases temperature and leads to self-heating. Moreover, temperature increases may produce decomposition reactions that enhance the ignition of the substance [1]. Therefore, this process becomes a danger from the point of view of industrial safety, in addition to transportation and storage. Some biomass treatment plants had accidents, due to this combustion process, as has been compiled by Krigstin et al. [2].

Any material capable of being oxidized by air may reach spontaneous combustion at a certain temperature. In the beginning, process is slow, and corresponds to material's exothermic oxidation, which produces a heat release. If the heat is not dissipated into the surrounding environment, it may generate a temperature increase. When the temperature rises, so does the oxidation reaction velocity, 
which means a greater heat production, that may rapidly accelerate to high temperatures able to ignite the material.

There are some other inner heat sources that may help self-heating processes, such as:

- Presence of compounds more oxidizable than the material itself, either because of contamination or naturally (as it happens with the presence of pyrite in coals) [3].

- Aerobic or anaerobic bacterial fermentation [4].

- Gaseous substance fixation, as the adsorption or condensation heat is high [5]. For example, water vapor fixation in some solvents on active coal

The importance of these processes and the consequences of the accidents produced by self-heating, result in extensive scientific research [6-8]. To determine the beginning of the process, different methods have been developed, most of them based on thermal analysis techniques, as thermogravimetry and differential scanning calorimetry $[9,10]$, as well as experimental techniques based on thermal decomposition [11], emission of flammable volatiles [12], critical self-ignition temperature [13], and exothermic reaction against peroxide attack [14].

A truly valuable method to quantify self-combustion risk is to determine the self-ignition temperature (SIT; according to EN 15188). The method is based on obtaining the environmental temperature at which the generated heat, due to the exothermic processes, is greater than the heat emitted to the environment, hence the heat build-up accelerates the oxidation reaction until ignition occurs. This temperature depends on the volume of the product submitted to these conditions, so that the higher the volume, the lower the self-ignition temperature. However, higher volumes increase induction time which is the period of time needed to raise the temperature of the product $60 \mathrm{~K}$ over the environmental temperature. This means that SIT will depend on time and volume. Experimentally, SIT is determined for different sample volumes under isothermal conditions and extrapolate the obtained results in order to predict at which temperature, the ignition of a certain sample will be produced, and the required time. Hence, this method turns to be useful for its application on great storage processes.

This method has been used previously to characterize the self-ignition of agricultural materials stored in silos [15,16], coals with different ranges and origin [17], biomasses [18], and thermally dried sewage sludge [19], among others. Research regarding numerical simulations has also been carried out $[20,21]$.

Moisture is one of the most important parameters regarding solid dust flammability, and whose study is one of the most difficult ones because it could help or hinder the material ignition. It has been noticed that small quantities of moisture may help the reaction as the reabsorption of moisture is an exothermic process that might accelerate the increase of temperature in a self-heating process [22]. However, when moisture percentage increases, it is more important its role as a thermal drain and involves water heating, retarding the beginning of the organic material heating. The influence of moisture on the self-ignition process has been widely studied [23].

Particle size also affects compaction, density, or particle aggregation; thus, it will have an effect on sample moisture. Usually, higher density or particle compaction means lower residual moisture.

On the other hand, the granulometry effect is simple: Fine particles help dust ignition, simply because the available surface area is increased. But, if those particles are too fine and devolatilization does not control the explosion rate [24], there will not be an increase in combustion rate among smaller sizes. In other words, when the particle size is increased, the devolatilization reaction takes place at higher temperatures. But, on the other hand, if very small particle sizes are considered, the differences between the granulometry will not be the dominant role in the ignition or explosion of the dust.

Particle size is an essential parameter for every ignition process, either when considering dust explosions [25] or when the product is dispersed in the air shaping a cloud before the possible ignition of the cloud. Under those conditions, the oxidation reaction that occurs over the particle surface is more rapidly accelerated, the greater the surface area is available. Therefore, granulometry is a key 
factor for ignition sensibility and explosion severity for dust clouds. Some models of particle size effect have been developed [26,27], but not considering self-ignition processes.

When the product is deposited as a layer or as a great pile, the importance of granulometry is not so obvious [28]. The influence of the compaction level has been studied and related to the thermal susceptibility using thermogravimetry analysis [29]. It has been observed that sample compaction increases its reactivity during pyrolysis processes, probably due to the heat conductivity increase. Differences in self-heating when testing pellets and un-compacted samples have also been studied [30]. When the material is stored in big piles, the accessibility of oxygen to the inner surface of the material may be reduced, and the oxidation reaction may be delayed [30]. When studying self-heating processes, it is very important to define the two mechanisms acting in the process: Conductivity contact with a hot surface and oxygen diffusion, due to air inlet inside the material particles.

It is well known that reaction progress might be affected by oxygen availability, hence greater compaction of a pile or layer will difficult the oxidation reaction progress. Besides that, compaction produces an increase in density and thermal conductivity, which means that self-heating tendency will be reduced because the material is able to evacuate the generated heat in an easier way, retarding self-ignition.

The influence of the granulometry on the ignition temperature of a dust layer was studied [31], noticing that such temperature decreases as the thickness of the layer increases, the particle size decreases, and the compaction of the product increases. The behavior of a material layer deposited on a warm surface is different from the behavior of a pile [32], such as an unthreshed grain. In the first scenario, the key factor is the thermal reaction propagation, as there is a great heat contribution through the hot surface. In the second scenario, access to oxygen is the essential parameter for the beginning of the reaction [33]. Moreover, when a fire is produced by biomass fuel, it is known that the thickness of the flame reaction zone is related to the particle size: As the particle size increases, so does the flame reaction zone thickness [34].

As it has been noticed, there are multiple parameters influencing self-ignition, and they may affect, to a greater or lesser, the extent the measured variables used to characterize the process. The aim of this study is to define the influence of a particular parameter: The granulometry on the spontaneous combustion properties of combustible solids, and on their possible classification for transportation.

\section{Materials and Methods}

The tested samples included different substances, such as wood biomass, agricultural biomass, or coals: Pine shaving (PS), wheat straw (WS), olive pellets (OP), two different brands of charcoal briquettes typically used in barbecues ( $\mathrm{Cb} 1$ and $\mathrm{Cb} 2)$ and dog food (DF). Table 1 shows the codes used for the sample's classification. The samples were subjected to six different tests: Granulometric analysis, moisture analysis, Classification test N.4 of Division 4.2 for self-heating substances, thermogravimetry (TGA), and differential scanning calorimetry (DSC) analysis, and gas emission test.

The tests were chosen in order to define different parameters related to self-heating processes. While the N4.2 test provides information regarding self-heating at isothermal conditions, it does not take into account the temperatures at which the process begins. On the other hand, TGA, DSC, and gas emission tests provide information about the beginning of the process, the stages of the same, and the temperatures at which they take places, but it does not consider heating mechanisms.

For each sample, three different sizes have been studied: Original product on its commercial shape (coarse), the sample milled with a particle size smaller than $1 \mathrm{~mm}$, and fine fraction smaller than $0.075 \mathrm{~mm}$. For the grinding of the samples, two different mills were used: A crusher and a blade mill. Afterward, sieving was carried out in order to obtain two differentiable fractions: Coarse fraction with a particle size just below $1 \mathrm{~mm}$, and fine fraction lower than $75 \mu \mathrm{m}$. After milling and sieving, a granulometric analysis was performed using laser diffraction Malvern Mastersizer 2000 instrument and obtaining a precise granulometric curve. Moisture was determined using Mettler Toledo HB43-S 
halogen analyzer. Because of its size, it was not possible to use the laser diffraction for the group of coarse samples, thus, the samples were measured manually and using sieves.

Table 1. Sample identification.

\begin{tabular}{cccc}
\hline Sample & Size Particle & Origin & Identification Code \\
\hline \multirow{2}{*}{ Pine shaving } & Coarse & Forestry & PS-C \\
& $<1 \mathrm{~mm}$ & residue Soria, & PS-1 \\
& $<75 \mu \mathrm{m}$ & Spain & PS-75 \\
& Coarse & Agricultural & WS-C \\
Wheat Straw & $<1 \mathrm{~mm}$ & residue Soria, & WS-1 \\
& $<75 \mu \mathrm{m}$ & Spain & WS-75 \\
\hline \multirow{3}{*}{ Charcoal (Brand 1) } & Coarse & & Cb1-C \\
& $<1 \mathrm{~mm}$ & Caceres, Spain & Cb1-1 \\
& $<75 \mu \mathrm{m}$ & & Cb1-75 \\
\hline \multirow{3}{*}{ Charcoal (Brand 2) } & Coarse & & Cb2-C \\
& $<1 \mathrm{~mm}$ & Badajoz, Spain & Cb2-1 \\
& $<75 \mu \mathrm{m}$ & & Cb2-75 \\
\hline \multirow{2}{*}{ Dog food } & Coarse & Commercially & DF-C \\
& $<1 \mathrm{~mm}$ & available & DF-1 \\
\hline \multirow{2}{*}{ Olive pellets } & Coarse & & OP-C \\
& $<1 \mathrm{~mm}$ & Granada, Spain & OP-1 \\
& $<75 \mu \mathrm{m}$ & & OP-75 \\
\hline
\end{tabular}

2.1. Test N.4 Test Method for Self-Heating Substances (United Nations Manual of Test and Criteria for Transport of Goods)

Once samples were prepared on the sizes described above, and the two mentioned basic characteristics were determined (moisture and precise particle size), the N4 4.2 Division test of the Manual of Tests and Criteria of the United Nations was carried out over all the samples [35].

This method characterizes self-combustion risk for different materials by assessing certain danger levels during transport, related to the volume of the product and the packing used. This method is part of a set of numerous and diverse tests universally used to establish the different risks that substances may have (such as an explosion, flammability, toxicity, corrosion, radioactivity, etc.), and there are many procedures or tests that assign to the substances a classification linked to an acceptable safety level for transport [36]. The European Agreement concerning the International Transport of Dangerous Goods by Road (ADR) assigns the 4.2 class to those materials that may spontaneously ignite.

For solids, the criteria for the classification of substances that experience spontaneous heating is based on the spontaneous ignition temperature of charcoal, which is $50{ }^{\circ} \mathrm{C}$ for a cubic sample of $27 \mathrm{~m}^{3}$ [37]. Test methodology, named $\mathrm{N} 4$ test, is based on applying this data to a $1 \mathrm{~L}$ volume, at which a self-ignition temperature of $140{ }^{\circ} \mathrm{C}$ will correspond. This test is also used as criteria for the transport of the International Maritime Dangerous Goods Code (IMDG).

When this method was applied to some dried sludge from wastewater, considered as a highly interesting biomass because of its energetic application, positive results were obtained, hence they are only exempt from classification if they are transported in packages smaller than $3 \mathrm{~m}^{3}$ [19].

The aim of this test is to determine if a substance undergoes self-heating spontaneously when having an air contact without energy supply or without an external ignition source. That kind of substance will ignite when they accumulate in large amounts and after a certain period of time.

The procedure consists of introducing the sample in a cubic cell of $100 \mathrm{~mm}$ side inside an oven that heats the cell (by convection) at $140{ }^{\circ} \mathrm{C}$ for $24 \mathrm{~h}$. Test turns out positive if the sample temperature increases more than $60 \mathrm{~K}$ over the set temperature, or self-ignition is produced. In that case, the test must be repeated, but using a $25 \mathrm{~mm}$ side cell; otherwise, the sample is not classified. If the second test 
is positive, then the test has to be repeated with a $100 \mathrm{~mm}$ side cell and a temperature of $120^{\circ} \mathrm{C}$ in the oven. Otherwise, the substance is exempted from classification when it is transported in packages smaller than $3 \mathrm{~m}^{3}$. If this third test is again positive, a fourth test must be carried on using a $100 \mathrm{~mm}$ side and $100{ }^{\circ} \mathrm{C}$, and if it is positive, the material is classified as Package Group III. If it is negative, then the material is exempted from classification if transported in packages of not more than $450 \mathrm{~L}$ volume [36].

By using thermocouples, the temperature of the sample and temperatures on the left side and on the right side of the oven, were obtained for $24 \mathrm{~h}$, which is the duration of the test, making it possible to draw a curve which represents the heating.

\subsection{Thermogravimetry and Differential Scanning Calorimetry Analysis}

Many authors have used thermogravimetry (TGA) and differential scanning calorimetry (DSC) analysis in order to define incipient combustion processes of biomass [14,38,39] and coals [40]. In this study, the temperature of combustion induction and maximum weight loss, which is related to the reactivity of the sample [29], were obtained from performing thermogravimetry analysis (TGA). TGA allows the measurement of the weight loss of a sample, while constant heating from $30^{\circ} \mathrm{C}$ until $800^{\circ} \mathrm{C}$ with a ratio of $5 \mathrm{~K} / \mathrm{min}$ is applied. In the last $10 \mathrm{~min}$ of the test, the sample remained at $800{ }^{\circ} \mathrm{C}$. The test is carried out in an air atmosphere, however if a more precise determination of the initial oxidation of the sample is wanted, TGA must be carried out using oxygen flow. In this case, instead of the temperature of maximum weight loss, a new parameter will be obtained: The so-called characteristic temperature $\left(\mathrm{T}_{\text {char }}\right)$. In both cases, TGA allows the study of oxidation reactions at high temperatures. The present work used both (air and oxygen flow) when performing TGA.

The exothermic processes can be defined by using the differential scanning calorimetry analysis (DSC). During the test, two crucibles were heated: One filled with the sample and one empty. The crucibles were heated with a constant ratio of $20 \mathrm{~K} / \mathrm{min}$ from $30^{\circ} \mathrm{C}$ until $550^{\circ} \mathrm{C}$. As the temperatures of the sample and the reference crucibles were measured, it is possible to define the exothermic and endothermic processes as the heatflow is recorded. When a sudden change of slope of the heatflow curve takes place, it defines the temperature at which the exothermic reaction accelerates. Both analyses, TGA and DSC, were carried out using a Mettler Toledo TG-50 instrument.

The data obtained from these analyses allowed the calculation of the apparent activation energy using Cumming's equation (1) [41], where the first order of kinetics is applied to the rate of weight loss:

$$
\ln \left(-\frac{1}{w} \cdot \frac{d w}{d t}\right)=\ln A \cdot \frac{E_{a}}{R T}
$$

where:

$w$ is the weight of unburnt sample ( $\mathrm{g}$ )

$d w / d t$ is the instantaneous rate of weight loss $\left(\mathrm{g} \cdot \mathrm{s}^{-1}\right)$

$A$ is the frequency factor $\left(\mathrm{s}^{-1}\right)$

$E_{a}$ is the apparent activation energy $\left(\mathrm{J} \cdot \mathrm{mol}^{-1}\right)$

$R$ is the universal gas constant $\left(8.314 \mathrm{~J} \cdot \mathrm{mol}^{-1} \mathrm{~K}^{-1}\right)$

$T$ is the absolute temperature $(\mathrm{K})$

\subsection{Gas Emission Analysis}

Gas emission analysis has been used before assessing oxidation processes related to self-heating and self-ignition of biomasses [42,43]. A fast and direct technique to detect the beginning of the self-combustion process consists of analyzing the air surrounding the stored or transported material in order to detect the presence of certain gases, such as $\mathrm{CO}$ and $\mathrm{CO}_{2}$, which are characteristic products of combustion reactions. Using a new methodology, it is possible to determine early oxidation processes [44]. 
Gas emission analysis has been carried out according to the method suggested by Fernandez Anez et al. [44]. The sample, inside a cubic cell of $100 \mathrm{~mm}$ side, was set inside a sealed container with a K-type thermocouple that allowed the reading of the sample temperature. The container was set inside an isothermal oven preheated at $20^{\circ} \mathrm{C}$. In addition, the container had a plastic tube connected to a suction pump allowing the filling of tedlar bags with the emitted gas from the sample. The temperature was increased up to $200{ }^{\circ} \mathrm{C}$, and gases were extracted every $20^{\circ} \mathrm{C}$. After full heating was carried out, the bags containing the gas samples were analyzed by means of a Rosemount Analytical NGA-2000 analyzer that determines $\mathrm{CO}$ and $\mathrm{CO}_{2}$ concentrations. Measurements were done at regular temperature intervals in steps of $20 \mathrm{~K}$.

The evaluation of the initial temperatures for both carbon monoxide and dioxide emissions, was carried out, calculating the relative differences for each temperature interval as (2):

$$
R D=\frac{e_{T i+1}-e_{T i}}{e_{T i}}
$$

where $e_{T i}$ is the gas emission at the lowest temperature of the interval, and $e_{T i+1}$ is the gas emission at the highest temperature of the interval. Using the relative differences, relative percentages were calculated as (3):

$$
R P=\frac{R D}{\sum R D_{i}} \cdot 100
$$

The temperature interval that corresponded to the first relative percentage greater than $10 \%$, was the initial temperature interval of gas emission.

\section{Results and Discussion}

The results of the particle size distributions measured using laser diffraction are presented in Table 2, which shows the size particle below 10\% (d10), 50\% (d50), and 90\% (d90) of the sample. The moisture was calculated as the arithmetic mean of three tests when the standard deviation is lower than $15 \%$, and ten tests when greater. The results of the moisture are shown in the same table.

\begin{tabular}{|c|c|c|c|c|}
\hline \multirow{2}{*}{ Sample } & \multicolumn{3}{|c|}{ Granulometric Analysis $[\mu \mathrm{m}]$} & \multirow{2}{*}{ Moisture [\%] } \\
\hline & d10 & d50 & d90 & \\
\hline PS-C & - & $8 \times 10^{3}$ & - & 7.7 \\
\hline PS-1 & 241.9 & 637.7 & 1302.7 & 7.9 \\
\hline PS-75 & 9.5 & 48.7 & 138.2 & 6.2 \\
\hline WS-C & - & $1.2 \times 10^{3}$ & - & 7.8 \\
\hline WS-1 & 68.7 & 298.1 & 890.9 & 7.1 \\
\hline WS-75 & 5.0 & 9.9 & 93.8 & 6.6 \\
\hline $\mathrm{Cb} 1-\mathrm{C}$ & - & $56 \times 10^{3}$ & - & 6.0 \\
\hline $\mathrm{Cb} 1-1$ & 56.3 & 364.5 & 879.7 & 5.9 \\
\hline $\mathrm{Cb} 1-75$ & 3.8 & 24.2 & 73.8 & 6.0 \\
\hline $\mathrm{Cb} 2-\mathrm{C}$ & - & $54 \times 10^{3}$ & - & 4.7 \\
\hline $\mathrm{Cb} 2-1$ & 4.5 & 22.8 & 101.6 & 5.0 \\
\hline $\mathrm{Cb} 2-75$ & 3.9 & 17.6 & 51.8 & 4.7 \\
\hline DF-C & - & $18 \times 10^{3}$ & - & - \\
\hline DF-1 & 22.8 & 217.3 & 712.7 & 7.0 \\
\hline OP-C & - & $150 \times 10^{3}$ & & - \\
\hline OP-1 & 111.6 & 415.5 & 1052.0 & 7.3 \\
\hline OP-75 & 3.9 & 41.2 & 104.3 & 7.0 \\
\hline
\end{tabular}

Table 2. Sample particle size and moisture.

Measuring particle size for biomass can present problems, due to the shapes of the biomass particle not only when presented in coarse size, but also after milling [45]. In this study, coarse samples presented different sizes and shapes. Thus, the results written in the table show the greater size 
considering length, width, and height. Pine shaving (PS-C) shaped as chips whose mean length was $8 \mathrm{~mm}$. Olive pellets (OP-C) shaped like cylinders with $5 \mathrm{~mm}$ diameter and $150 \mathrm{~mm}$ length. Both brands of charcoal samples (Cb1-C and Cb2-C) were briquettes $2 \mathrm{~mm}$ in width, and 56 and $54 \mathrm{~mm}$ in mean length. Dog food (DF-C) presented different shapes as chips and small bricks, so the greater mean length was considered (18 $\mathrm{mm})$.

Particle shape also affected the finer particles results. Samples as olive pellets and pine shaving might be filament-shaped after milling, so that they may go through the sieve mesh. However, when applying a more accurate method as laser diffraction, it can be seen that particle size is greater than the sieve mesh size $(1 \mathrm{~mm}$ or $75 \mu \mathrm{m})$. Milling the other samples produced powder with somehow spherical particles, so this difference between sieve and laser diffraction was not present.

Regarding the N4 4.2 United Nations test, a temperature versus time graph is obtained. The test was carried out using three K-type thermocouples: Two outside the sample (to the right and left) and one inside the basket that contains the sample. The thermocouples outside the sample measured oven temperature, while the one inside the basket provided sample temperature. When the sample presented self-heating, the sample thermocouple recorded higher temperatures than the other two. When not, the three thermocouples remained at the oven temperature along with all the test time. Because of that, when plotting results, only the sample thermocouple was represented.

For the samples used, the test turned to be negative in most of the cases, meaning that the sample did not need classification according to the UN normative. However, when testing Cb1-75, Cb2-1, and $\mathrm{Cb} 2-75$, the result changed; those samples were classified as exempted from classification when only transported in piles smaller than $3 \mathrm{~m}^{3}$. It means that, for different particle sizes of the same material, two different classifications may be obtained. This is a very important result, since it greatly affects the possible classification of some products and shows how heat transfer mechanisms may vary depending on granulometry in a more intensive way than composition or moisture.

Figure 1 shows the charcoals samples thermocouple record in the three different sizes described previously. In this figure, it is possible to see the two possible results from the test: Positive (when the temperature rises) and negative (when only reaches just the oven temperature or in case the sample temperature surpasses less than $60 \mathrm{~K}$ the oven temperature).

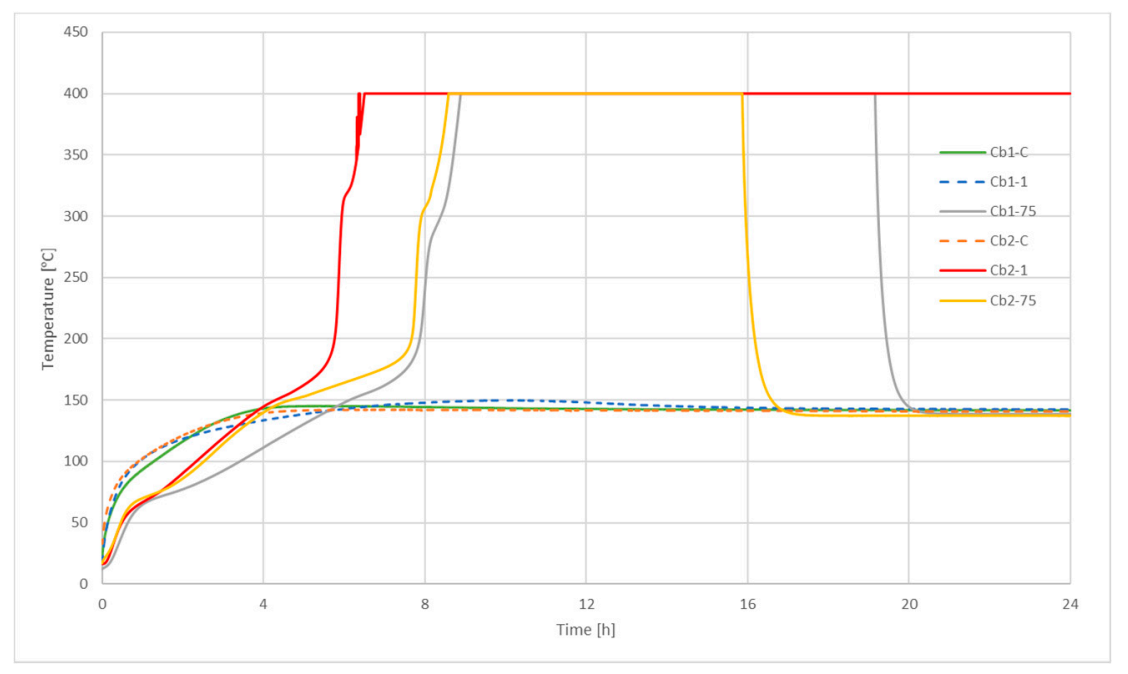

Figure 1. United Nations N4.2 Test for charcoal.

Charcoal brand 2 presented results more susceptible to self-heating, as only the coarse charcoal did not increase its temperature over $140{ }^{\circ} \mathrm{C}$ of the oven, while the other two sizes reached $400{ }^{\circ} \mathrm{C}$-the temperature at which the thermal signal register gets saturated-in the first step of the experiment. The other sample (charcoal brand 1) only raised its temperature over the oven temperature when tested in particle sizes lower than $75 \mu \mathrm{m}$. As mentioned, the figure plots the first step of the experiment when 
the sample is inside a $100 \mathrm{~mm}$ side cubic basket at $140{ }^{\circ} \mathrm{C}$, so further tests were carried out in other to fulfill the whole procedure. Charcoal samples with particle sizes lower than $75 \mu \mathrm{m}$ were exempt from classification only if transported in packages smaller than $3 \mathrm{~m}^{3}$, and so was $\mathrm{Cb} 2-1$.

As it has been said, the N4.2 test provides basic information about self-heating and requires further studies and literature data to fully assess the process. The results obtained in this test can be contrasted with data previously obtained [46] for the self-ignition temperature (SIT) of wheat dust, whose composition and particle size are similar. Those data showed that when testing a $1.5 \mathrm{~L}$ basket the SIT turned to be greater than $152.5^{\circ} \mathrm{C}$. As N4.2 oven temperature is $140{ }^{\circ} \mathrm{C}$, self-ignition will not be produced, and a negative result was obtained WS-1 and WS-75 samples. The same referenced paper presents SIT for different coals (also dust), and all but one, have temperatures equal or lower than $140{ }^{\circ} \mathrm{C}$, that fit the positive result of the $\mathrm{N} 4.2$ test for the charcoal samples.

The thermogravimetry and differential scanning calorimetric analyses can only be performed with fine particle size, as the crucible's volume is $70 \mu \mathrm{L}$. The samples tested were those with particle sizes lower than $75 \mu \mathrm{m}$ (except for dog food, whose smallest particle size is $<1 \mathrm{~mm}$ ). Even no difference between granulometric effects can be seen using those analyses; it provides information regarding self-heating and self-ignition processes: It defines the main kinetic parameters of the materials, such as the apparent activation energy $\left(E_{a}\right)$, induction temperature when using air $\left(I T_{a i r}\right)$ and oxygen flow $\left(I T_{\text {oxygen }}\right)$, characteristic temperature $\left(T_{\text {char }}\right)$, temperature of maximum weight loss $(M L T)$, temperature of change of slope (CST), initial temperature of the exothermic reaction (IET), and final temperature of the exothermic reaction (FET). Those parameters can be shown in Table 3 for every sample.

Table 3. Main combustion parameters.

\begin{tabular}{ccccccccc}
\hline Sample & $\boldsymbol{E}_{\boldsymbol{a}}(\mathbf{k J} / \mathbf{m o l})$ & $\boldsymbol{I T}_{\text {oxygen }}\left({ }^{\circ} \mathbf{C}\right)$ & $\boldsymbol{T}_{\text {char }}\left({ }^{\circ} \mathbf{C}\right)$ & $\boldsymbol{I T}_{\text {air }}\left({ }^{\circ} \mathbf{C}\right)$ & $\boldsymbol{M L T}\left({ }^{\circ} \mathbf{C}\right)$ & $\boldsymbol{C S T}\left({ }^{\circ} \mathbf{C}\right)$ & $\operatorname{IET}\left({ }^{\circ} \mathbf{C}\right)$ & FET $\left({ }^{\circ} \mathbf{C}\right)$ \\
\hline PS-75 & 57.3 & 244 & 289 & 257 & 330 & 377.9 & 311 & 449 \\
WS-75 & 63.6 & 237 & 268 & 255 & 309 & 347.9 & 227 & 457 \\
Cb1-75 & 79.2 & 358 & 404 & 271 & 293 & 261.1 & 200 & 321 \\
Cb2-75 & 85.9 & 342 & 389 & 361 & 465 & 170.6 & 133 & 498 \\
DF-1 & 67.8 & 256 & 269 & 255 & 279 & 416.4 & 330 & 536 \\
OP-75 & 79.4 & 257 & 266 & 245 & 289 & 259.3 & 200 & 331 \\
\hline
\end{tabular}

Biomasses present lower IT and $T_{\text {char }}$ values than charcoal, but the N4 Div.4.2 test was negative for biomass and positive for charcoal. It means that having lower combustion induction temperature does not guarantee self-ignition processes, which is not an unusual result as it may seem: It happens because the heat transfer processes are less effective in biomasses than charcoals. Self-ignition processes are likely to succeed when testing charcoal because of the effectiveness of the heat transfer, even if its IT is great.

Figures 2-4 show the TGA curves for air atmosphere, TGA curves for oxygen atmosphere, and DSC curves, respectively. TGA plots include the first derivative of the curve (DTG) as it defines the maximum weight loss temperature. It can be seen in Figures 2 and 3, that charcoals samples required higher temperatures for beginning the reaction, as shown in Table 3. Some differences may be noted when comparing the induction temperature when using air flow and oxygen flow. These differences are due to the concentration of oxygen of the samples, especially regarding the Cb1-75 sample.

Those samples present the higher content of ashes, which means that the char after the test is greater in those cases. On the other hand, pine shaving and olive pellets samples present the lower content of ashes, and there is almost no residue at the end of the test. Biomass and dog food samples present similar induction temperatures, which means that the combustion reaction begins between $230^{\circ} \mathrm{C}$ and $260^{\circ} \mathrm{C}$. However, as those samples have different compositions, MLT and characteristic temperature differ from one sample to another. 


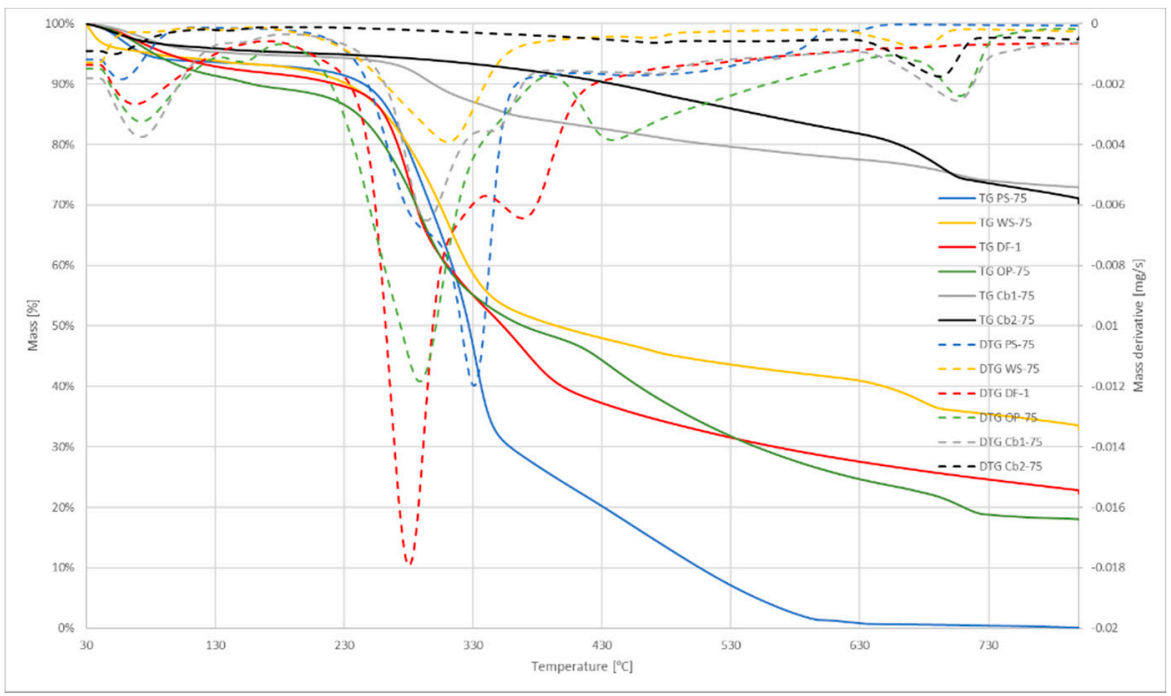

Figure 2. Air atmosphere TG and DTG curves.

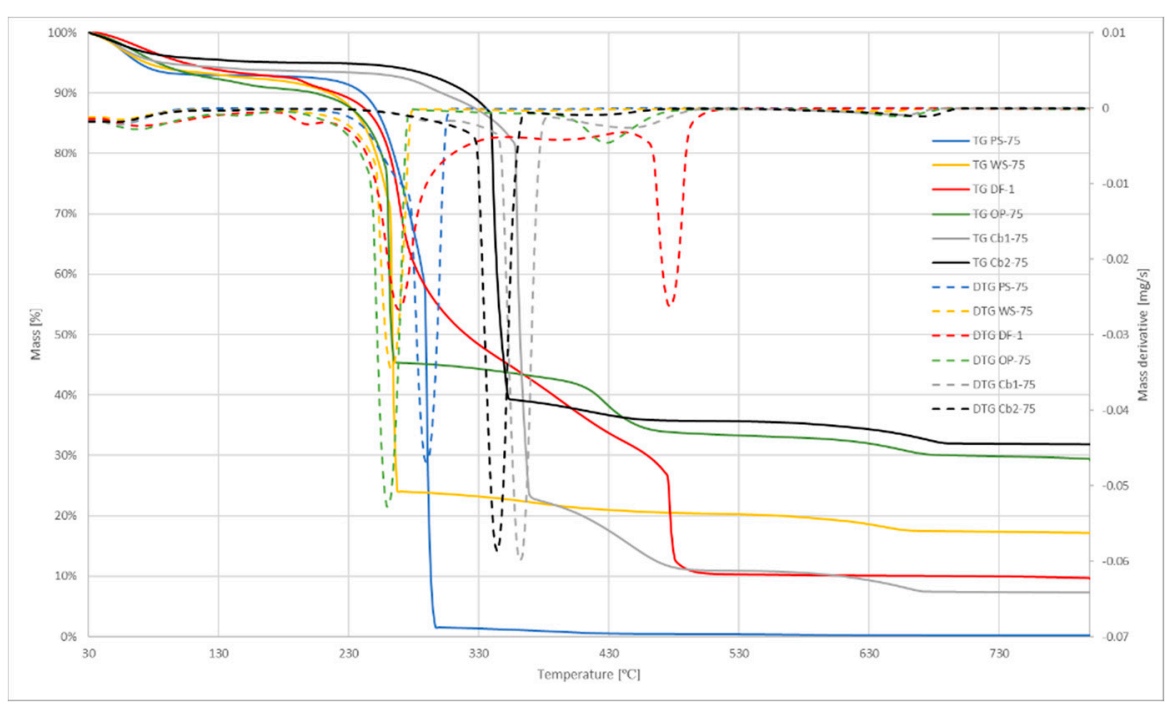

Figure 3. Oxygen atmosphere TG and DTG curves.

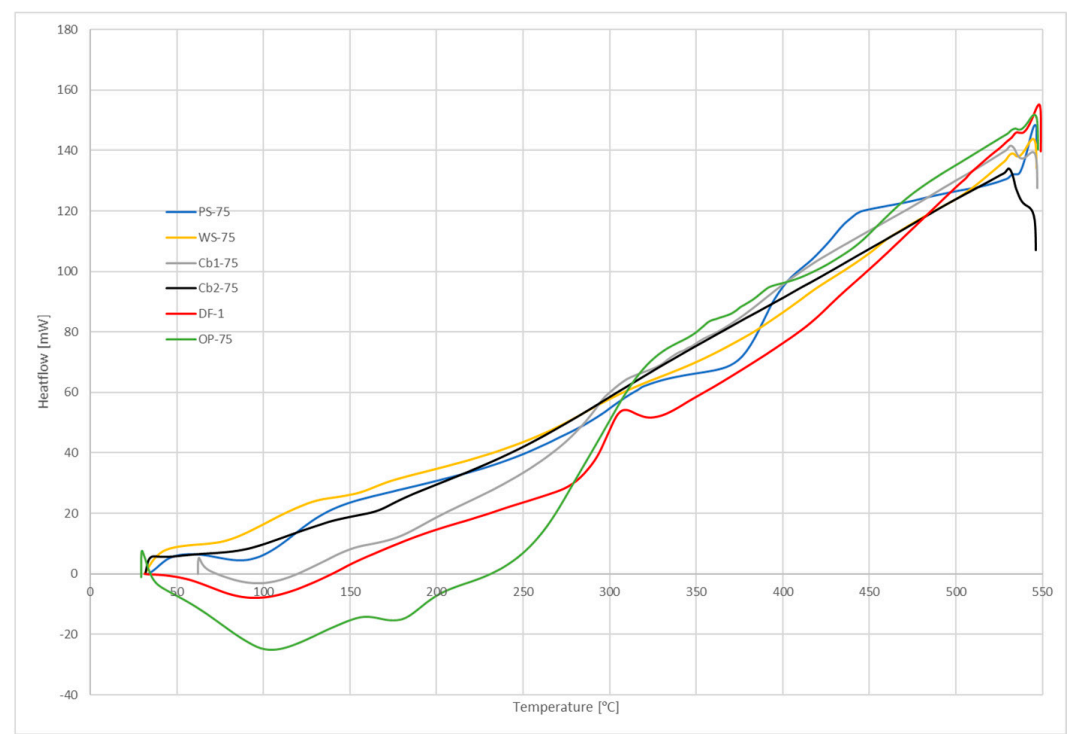

Figure 4. Differential scanning calorimetry (DSC) curves. 
These differences in composition can also be seen in the shapes of DTG curves, as the peaks of these curves represent the volatilization of light and heavy volatiles. It means that two different stages took place during the process: Devolatilization of light volatiles and devolatilization of heavy volatiles. Figure 3 shows those different peaks more clearly, and also the stages of the process. DSC results (Figure 4) also show those different stages: The more separated were the peaks in DTG curves, the more pronounced was the change of slope seen in DSC curves.

The apparent activation energy has been calculated using TGA performed with oxygen flow results, as the self-ignition risk (outlined below) is determined by using $E_{a}$ and characteristic temperature, only available when using oxygen flow.

Medic et al. [47] compile a self-ignition risk classification depending on the apparent activation energy and the characteristic temperature, classifying the risk into four different categories: Low (green), medium (yellow), high (orange), very high (red). The obtained activation energy results were in between the 57 and $86 \mathrm{~kJ} / \mathrm{mol}$ range. Charcoal samples presented higher activation energies followed by $\operatorname{dog}$ food. The $E_{a}$ values obtained for biomasses were similar to Medic et al. [47] results. The same conclusion for biomasses was obtained: It is easy for the biomasses to start a self-heating process, but it does not usually succeed, due to their composition [48]. Figure 5 shows a self-ignition chart, where biomasses and dog food present a high risk of self-ignition and charcoal samples low risk. This result agrees with the obtained data from TGA seen in Table 3: Biomass requires higher temperatures for self-heating than charcoal, however biomass composition usually suffocates the process, while charcoal feeds it.

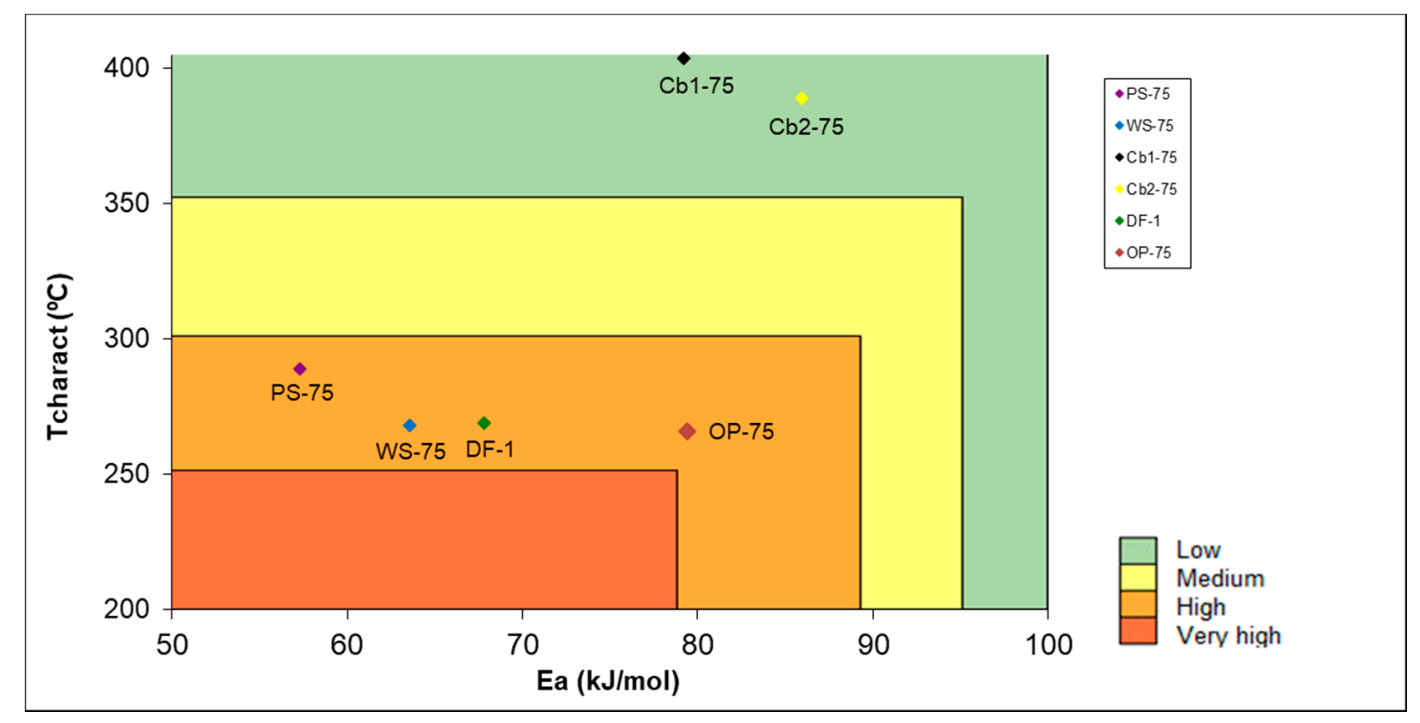

Figure 5. Self-ignition risk.

On the other hand, charcoal samples presented a smaller particle size, and as said before, biomass dust has different and not uniform shapes. This means that, even if charcoal is placed at the low self-ignition risk zone, its composition and particle size contributes to self-heating process, as seen in N4.2 test results. Biomass may begin the process with lower temperatures, but the available surface (related to the shape) and particle size interfere with the propagation of the process, sometimes even inhibiting it.

Gas emission analysis has been carried out for all samples for two or three different particle sizes to see if there is a significant change in the initial gas emission temperature (IGET) as the granulometry changes. The gas analyzer provides the volumetric percentage of $\mathrm{CO}_{2}$ and volumetric $\mathrm{ppm}_{\mathrm{v}}\left(\mathrm{mL} / \mathrm{m}^{3}\right)$ of $\mathrm{CO}$, but even with different metrics, the procedure explained before for the temperature interval of initial emissions is valid. 
The obtained results for the gas emission interval temperature are shown in Table 4. It can be noticed that the greater the particle sizes of the sample, the higher the temperature at which gas combustion-related emissions start in most of the samples. It means that coarse samples produce combustion-related gases at higher temperatures; in other words, granulometry affects combustion. It was also noticed that $\mathrm{CO}$ emissions have a lower range of temperatures than $\mathrm{CO}_{2}$, which means that the $\mathrm{CO}$ emissions are produced before $\mathrm{CO}_{2}$. It was noticed that great differences were produced between coarse and fine samples, but not so much between intermediate $(<1 \mathrm{~mm})$ and fine samples $(<75 \mu \mathrm{m})$.

Table 4. Initial gas emission interval temperature.

\begin{tabular}{cccccc}
\hline Sample & T. for $\mathbf{C O}\left({ }^{\circ} \mathbf{C}\right)$ & T. for $\mathbf{C O}_{2}\left({ }^{\circ} \mathbf{C}\right)$ & Sample & T. for CO $\left({ }^{\circ} \mathbf{C}\right)$ & T. for $\mathbf{C O}_{2}\left({ }^{\circ} \mathbf{C}\right)$ \\
\hline PS-C & $80-100$ & $60-80$ & Cb2-C & $80-100$ & $100-120$ \\
PS-1 & $60-80$ & $60-80$ & Cb2-1 & $40-60$ & $60-80$ \\
WS-C & $60-80$ & $60-80$ & Cb2-75 & $40-60$ & $60-80$ \\
WS-1 & $40-60$ & $40-60$ & DF-C & $40-60$ & $40-60$ \\
Cb1-C & $80-100$ & $100-120$ & DF-1 & $40-60$ & $40-60$ \\
Cb1-1 & $60-80$ & $60-80$ & OP-C & $60-80$ & $100-120$ \\
Cb1-75 & $60-80$ & $40-60$ & OP-1 & $60-80$ & $60-80$ \\
\hline
\end{tabular}

This method for gas emission evaluation does not show precisely enough the IGET, but a range, making it difficult to see the differences between coarse and fine particle size in some of the samples. However, when plotting the gathered data (Figure 6), the curves show important differences, as usually the maximum emissions measured were reached before in fine samples than coarse ones. This means that particle size not only affects the IGET, but also the velocity at which the emissions are produced. When the available surface is greater, the process accelerates rapidly, increasing those emissions.
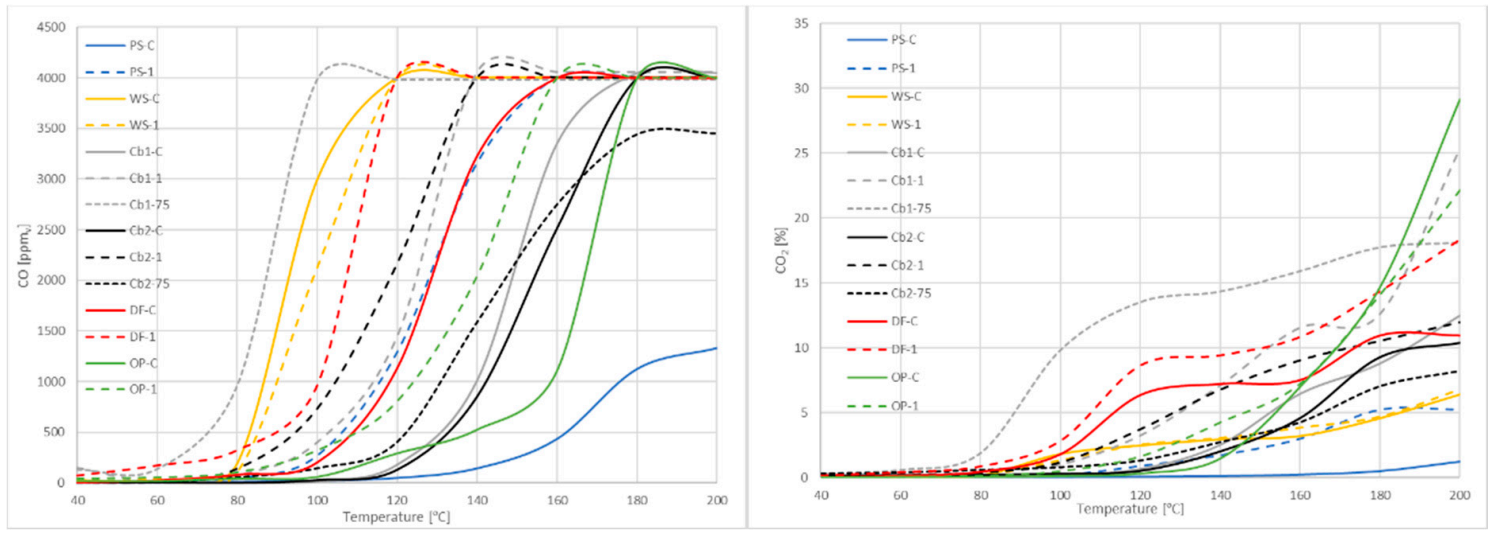

Figure 6. Gas emission.

\section{Conclusions}

The results show the main combustion parameters for six different materials in different particle sizes. It has been shown the importance of the granulometry on those parameters, as they have very significant changes depending on the particle size. As it was noticed, granulometry may have an important impact on the storage and transport standards and should be taken into account. According to that, some test procedures should define the particle size needed for the test in order to properly obtain the combustion parameters of the material.

TGA results provided information regarding the beginning of the combustion and the stages of the process, and as the self-ignition risk classification, the results show that the method only takes into account the fine particles and omits the heat transfer mechanisms. Biomass is easier to be heated than charcoal, but it is harder to transfer heat because most biomasses have complex structures. This explains why self-heating processes turn to be more efficient in charcoals than biomasses. 
The method used for gas emission assessment gives very useful information about early detection of the self-ignition process, but needs to be improved because, as shown in Figure 6, the ranges that result from this method are not capable of providing substantial differences that actually exist. The differences between coarse and fine samples regarding gas emission tests are considered enough to see how granulometry affects IGET. At the same time, those gases are highly related to combustion reactions; the difference between IGET means that there are differences between combustion reactions of the same material at different size particles.

Further research is needed to more precisely define the relationship between particle size and compaction. This would provide more complete knowledge of those properties and give recommendations that completes the current regulations-which should include a clear indication on the granulometry of the product to be classified.

Author Contributions: Conceptualization, J.G.T.; Methodology, B.C. and L.M., Validation, B.C. and I.A.; Formal Analysis, B.C. and J.G.T.; Investigation, B.C. and I.A.; Data Curation, B.C.; Writing-Original Draft Preparation, B.C.; Writing-Review \& Editing, J.G.T., I.A., L.M.; Supervision, J.G.T. All authors have read and agreed to the published version of the manuscript.

Funding: This research received no external funding.

Conflicts of Interest: The authors declare no conflict of interest.

\section{References}

1. Ren, X.; Chen, J.; Li, G.; Wang, Y.; Lang, X.; Fan, S. Thermal oxidative degradation kinetics of agricultural residues using distributed activation energy model and global kinetic model. Bioresour. Technol. 2018, 261, 403-411. [CrossRef]

2. Krigstin, S.; Wetzel, S.; Jayabala, N.; Helmeste, C.; Madrali, S.; Agnew, J.; Volpe, S. Recent Health and Safety Incident Trends Related to the Storage of Woody Biomass: A Need for Improved Monitoring Strategies. Forests 2018, 9, 538. [CrossRef]

3. Per'ochová, M.; Derychova, K.; Veznikova, H.; Bernatik, A.; Pitt, M. The influence of oxygen concentration on the composition of gaseous products occurring during the self-heating of coal and wood sawdust. Process. Saf. Environ. Prot. 2015, 94, 463-470. [CrossRef]

4. Hogland, W.; Marques, M. Physical, biological and chemical processes during storage and spontaneous combustion of waste fuel. Resour. Conserv. Recycl. 2003, 40, 53-69. [CrossRef]

5. Malow, M.; Krause, U. Smoldering combustion of solid bulk materials at different volume fractions of oxygen in the surrounding gas. Fire Saf. Sci. 2008, 9, 303-314. [CrossRef]

6. Dobashi, R. Studies on accidental gas and dust explosions. Fire Saf. J. 2017, 91, 21-27. [CrossRef]

7. Rupar-Gadd, K.; Forss, J. Self-heating properties of softwood samples investigated by using isothermal calorimetry. Biomass Bioenergy 2018, 111, 206-212. [CrossRef]

8. Veznikova, H.; Perd'ochová, M.; Bernatik, A.; Binkau, B. Safe storage of selected fuels with regard to their tendency to spontaneous combustion. J. Loss Prev. Process. Ind. 2014, 29, 295-299. [CrossRef]

9. Saldarriaga, J.F.; Aguado, R.; Pablos, A.; Amutio, M.; Olazar, M.; Bilbao, J. Fast characterization of biomass fuels by thermogravimetric analysis (TGA). Fuel 2015, 140, 744-751. [CrossRef]

10. Collazo, J.; Pazó, J.A.; Granada, E.; Savedra, Á.; Eguía, P. Determination of the specific heat of biomass materials and the combustion energy of coke by DSC analysis. Energy 2012, 45, 746-752. [CrossRef]

11. Nowicki, L.; Ledakowicz, S. Comprehensive characterization of thermal decomposition of sewage sludge by TG-MS. J. Anal. Appl. Pyrolysis 2014, 110, 220-228. [CrossRef]

12. Zhao, F.-J.; Shu, L.-F.; Wang, Q.-H.; Wang, M.-Y.; Tian, X.-R. Emissions of volatile organic compounds from heated needles and twigs of Pinus pumila. J. For. Res. 2011, 22, 243-248. [CrossRef]

13. Rifella, A.; Setyawan, D.; Chun, D.H.; Yoo, J.; Kim, S.D.; Rhim, Y.J.; Choi, H.K.; Lim, J.; Lee, S.; Rhee, Y. The effects of coal particle size on spontaneous combustion characteristics. Int. J. Coal Prep. Util. 2019, 1-25. [CrossRef]

14. Restuccia, F.; García-Torrent, J.; Medic-Pejic, L. Flammability properties of thermally dried sewage sludge. Fuel 2014, 134, 636-643. [CrossRef] 
15. Jones, J.M.; Saddawi, A.; Dooley, B.; Mitchell, E.; Werner, J.; Waldron, D.; Weatherstone, S.; Williams, A. Low temperature ignition of biomass. Fuel Process. Technol. 2015, 134, 372-377. [CrossRef]

16. Ramírez-Gómez, Á.; García-Torrent, J.; Tascón, A. Experimental determination of self-heating and self-ignition risks associated with the dusts of agricultural materials commonly stored in silos. J. Hazard. Mater. 2010, 175, 920-927. [CrossRef]

17. Reddy, P.D.; Amyotte, P.; Pegg, M.J. Effect of Inerts on Layer Ignition Temperatures of Coal Dust. Combust. Flame 1998, 114, 41-53. [CrossRef]

18. Torrent, J.G.; Anez, N.F.; Pejic, L.M.; Mateos, L.M. Assessment of self-ignition risks of solid biofuels by thermal analysis. Fuel 2015, 143, 484-491. [CrossRef]

19. Pejic, L.M.; Restuccia, F.; Torrent, J.G.; Ramírez-Gómez, Á. Determination of spontaneous combustion of thermally dried sewage sludge. J. Loss Prev. Process. Ind. 2015, 36, 352-357. [CrossRef]

20. Mahmoudi, A.H.; Hoffmann, F.; Markovic, M.; Peters, B.; Brem, G. Numerical modeling of self-heating and self-ignition in a packed-bed of biomass using XDEM. Combust. Flame 2016, 163, 358-369. [CrossRef]

21. Wu, D.; Schmidt, M.; Berghmans, J. Spontaneous ignition behaviour of coal dust accumulations: A comparison of extrapolation methods from lab-scale to industrial-scale. Proc. Combust. Inst. 2019, 37, 4181-4191. [CrossRef]

22. Eckhoff, R.K. Explosion Hazards in the Process Industries; Gulf Publishing Company: Houston, TX, USA, 2005. [CrossRef]

23. Lohrer, C.; Schmidt, M.; Krause, U. A study on the influence of liquid water and water vapour on the self-ignition of lignite coal-experiments and numerical simulations. J. Loss Prev. Process. Ind. 2005, 18, 167-177. [CrossRef]

24. Melgar, A.; Pérez, J.F.; Borge, D. Kynetic study of the biomass devolatilization process in particles sizes between 2-19 mm by means of thermogravimetric analysis. DYNA 2008, 75, 123-131. Available online: http://www.scielo.org.co/scielo.php?script=sci_arttext\&pid=S0012-73532008000200012\&nrm=iso (accessed on 17 January 2019).

25. Eckhoff, R. Understanding dust explosions. The role of powder science and technology. J. Loss Prev. Process. Ind. 2009, 22, 105-116. [CrossRef]

26. Russo, P.; Amyotte, P.R.; Khan, F.I.; Di Benedetto, A. Modelling of the effect of size on flocculent dust explosions. J. Loss Prev. Process. Ind. 2013, 26, 1634-1638. [CrossRef]

27. Di Benedetto, A.; Russo, P.; Amyotte, P.; Marchand, N. Modelling the effect of particle size on dust explosions. Chem. Eng. Sci. 2010, 65, 772-779. [CrossRef]

28. Wu, D.; Song, Z.; Schmidt, M.; Zhang, Q.; Qian, X. Theoretical and numerical study on ignition behaviour of coal dust layers on a hot surface with corrected kinetic parameters. J. Hazard. Mater. 2019, 368, 156-162. [CrossRef]

29. Mateos, L.M.; Garcia-Torrent, J.; Gómez, J.C.; Fernandez-Anez, N.; Medic, L. Physical Characteristics of Biomass and Its Influence in Self-Combustion. In Proceedings of the 13th SGEM GeoConference Energy and Clean Technologies, Albena, Bulgaria, 16-22 June 2013; STEF92 Technology Ltd.: Sofia, Bulgaria, 2013; pp. 169-176. [CrossRef]

30. Restuccia, F.; Fernandez-Anez, N.; Rein, G. Experimental measurement of particle size effects on the self-heating ignition of biomass piles: Homogeneous samples of dust and pellets. Fuel 2019, 256, 115838. [CrossRef]

31. Fernandez-Anez, N.; Garcia-Torrent, J.; Medic, L.; Olmedo, C.G. Influence of grain size and compaction of different solid fuels on the layer ignition temperature. In Proceedings of the II International Congress of Chemical Engineering of ANQUE, ICCE, BIOTEC, Abstracts, Madrid, Spain, 1-4 July 2014; p. 483. Available online: http://oa.upm.es/36400/ (accessed on 21 February 2019).

32. Janes, A.; Carson, D.; Accorsi, A.; Chaineaux, J.; Tribouilloy, B.; Morainvillers, D. Correlation between self-ignition of a dust layer on a hot surface and in baskets in an oven. J. Hazard. Mater. 2008, 159, 528-535. [CrossRef]

33. Krigstin, S.; Helmeste, C.; Jia, H.; Johnson, K.E.; Wetzel, S.; Volpe, S.; Faizal, W.; Ferrero, F. Comparative analysis of bark and woodchip biomass piles for enhancing predictability of self-heating. Fuel 2019, 242, 699-709. [CrossRef]

34. Zhang, H.; Chen, X.; Zhang, Y.; Niu, Y.; Yuan, B.; Dai, H.; He, S. Effects of particle size on flame structures through corn starch dust explosions. J. Loss Prev. Process. Ind. 2017, 50, 7-14. [CrossRef] 
35. United Nations (ONU). Recommendations on the Transport of Dangerous Goods: Manual of Tests and Criteria-5th Revised Edition; United Nations: New York, NY, USA, 2009. [CrossRef]

36. United Nations. Recomendations on the Transport of Dangerous Goods: Manual of Tests and Criteria; United Nations: New York, NY, USA, 2015.

37. United Nations. Recommendations on the Transport of Dangerous Goods: Model Regulations; United Nations: New York, NY, USA, 2009.

38. Li, M.; Xiao, B.; Wang, X.; Liu, J. Consequences of sludge composition on combustion performance derived from thermogravimetry analysis. Waste Manag. 2015, 35, 141-147. [CrossRef] [PubMed]

39. Magdziarz, A.; Wilk, M. Thermogravimetric study of biomass, sewage sludge and coal combustion. Energy Convers. Manag. 2013, 75, 425-430. [CrossRef]

40. Janković, B.; Manić, N.G.; Stojiljković, D.; Jovanovic, V. The assessment of spontaneous ignition potential of coals using TGA-DTG technique. Combust. Flame 2020, 211, 32-43. [CrossRef]

41. Cumming, J.W. Reactivity assessment of coals via a weighted mean activation energy. Fuel 1984, 63, 1436-1440. [CrossRef]

42. Sedlmayer, I.; Arshadi, M.; Haslinger, W.; Hofbauer, H.; Larsson, I.; Lönnermark, A.; Nilsson, C.; Pollex, A.; Schmidl, C.; Stelte, W.; et al. Determination of off-gassing and self-heating potential of wood pellets-Method comparison and correlation analysis. Fuel 2018, 234, 894-903. [CrossRef]

43. Bluvshtein, N.; Villacorta, E.; Li, C.; Hagen, B.C.; Frette, V.; Rudich, Y. Early detection of smoldering in silos: Organic material emissions as precursors. Fire Saf. J. 2020, 114, 103009. [CrossRef]

44. Restuccia, F.; Torrent, J.G.; Pejic, L.M.; Olmedo, C.G. Detection of incipient self-ignition process in solid fuels through gas emissions methodology. J. Loss Prev. Process. Ind. 2015, 36, 343-351. [CrossRef]

45. Guo, Q.; Chen, X.; Liu, H. Experimental research on shape and size distribution of biomass particle. Fuel 2012, 94, 551-555. [CrossRef]

46. García-Torrent, J.; Ramírez-Gómez, Á.; Querol-Aragón, E.; Grima-Olmedo, C.; Medic-Pejic, L. Determination of the risk of self-ignition of coals and biomass materials. J. Hazard. Mater. 2012, 213-214, 230-235. [CrossRef]

47. Medic-Pejic, L.; Restuccia, F.; Rubio-Arrieta, L.; Garcia-Torrent, J. Thermal behaviour of organic solid recovered fuels (SRF). Int. J. Hydrog. Energy 2016, 41, 16556-16565. [CrossRef]

48. Vassilev, S.V.; Vassileva, C.G.; Vassilev, V.S. Advantages and disadvantages of composition and properties of biomass in comparison with coal: An overview. Fuel 2015, 158, 330-350. [CrossRef]

Publisher's Note: MDPI stays neutral with regard to jurisdictional claims in published maps and institutional affiliations.

(C) 2020 by the authors. Licensee MDPI, Basel, Switzerland. This article is an open access article distributed under the terms and conditions of the Creative Commons Attribution (CC BY) license (http://creativecommons.org/licenses/by/4.0/). 